University of Nebraska - Lincoln

DigitalCommons@University of Nebraska - Lincoln

Faculty Publications: Department of Teaching, Department of Teaching, Learning and Teacher Learning and Teacher Education

Education

$2-2-2020$

\title{
Insights into nature of science and evolution education
}

Lawrence C. Scharmann

University of Nebraska-Lincoln, Ischarmann2@unl.edu

Follow this and additional works at: https://digitalcommons.unl.edu/teachlearnfacpub

Part of the Curriculum and Instruction Commons, and the Teacher Education and Professional Development Commons

Scharmann, Lawrence C., "Insights into nature of science and evolution education" (2020). Faculty Publications: Department of Teaching, Learning and Teacher Education. 377.

https://digitalcommons.unl.edu/teachlearnfacpub/377

This Article is brought to you for free and open access by the Department of Teaching, Learning and Teacher Education at DigitalCommons@University of Nebraska - Lincoln. It has been accepted for inclusion in Faculty Publications: Department of Teaching, Learning and Teacher Education by an authorized administrator of DigitalCommons@University of Nebraska - Lincoln. 
Education \& Training | Lawrence C. Scharmann

\section{Insights into nature of science and evolution education}

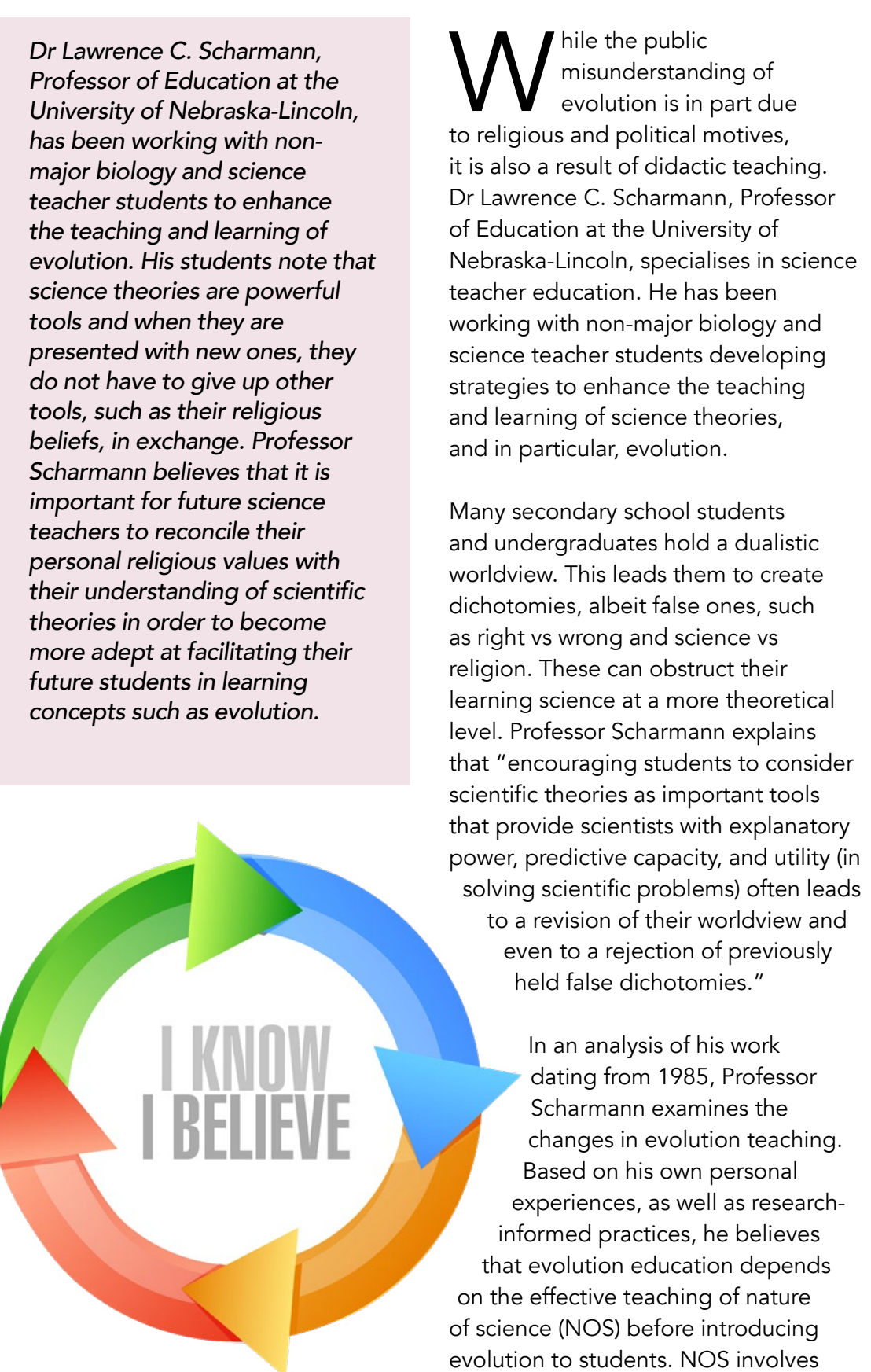

recognising that scientific knowledge is underpinned by various levels and a variety of social aspects.

\section{FOUR INSIGHTS} acumens that establish a pedagogy that he and his colleagues have found effective in supporting students, especially non-science majors, in the study of evolutionary science. He recommends that explicit NOS principles should be taught first, before other science concepts are introduced. Following this, evolution can be integrated throughout an introductory biology course as a theme, and linked to NOS principles. He also recommends that active learning pedagogies are 'teployed to promote students' critical . student-to-student interactions in pairs, groups, and teams, instructorto-student interactions involving question and answer sessions and whole class discussion, trains students to manage their perceptions of science controversies. Finally, non-threatening alternative assessments should be used to enhance the students' learning and acceptance of evolutionary science.

\section{EVOLUTION INSTRUCTION} FACILITATING NATURE OF SCIENCE UNDERSTANDING Professor Scharmann has observed how teaching evolution can facilitate students' understanding the nature of science. He designs his courses
primarily to establish how evolutionary sased on assumptions and scien

Professor Scharmann puts forward four

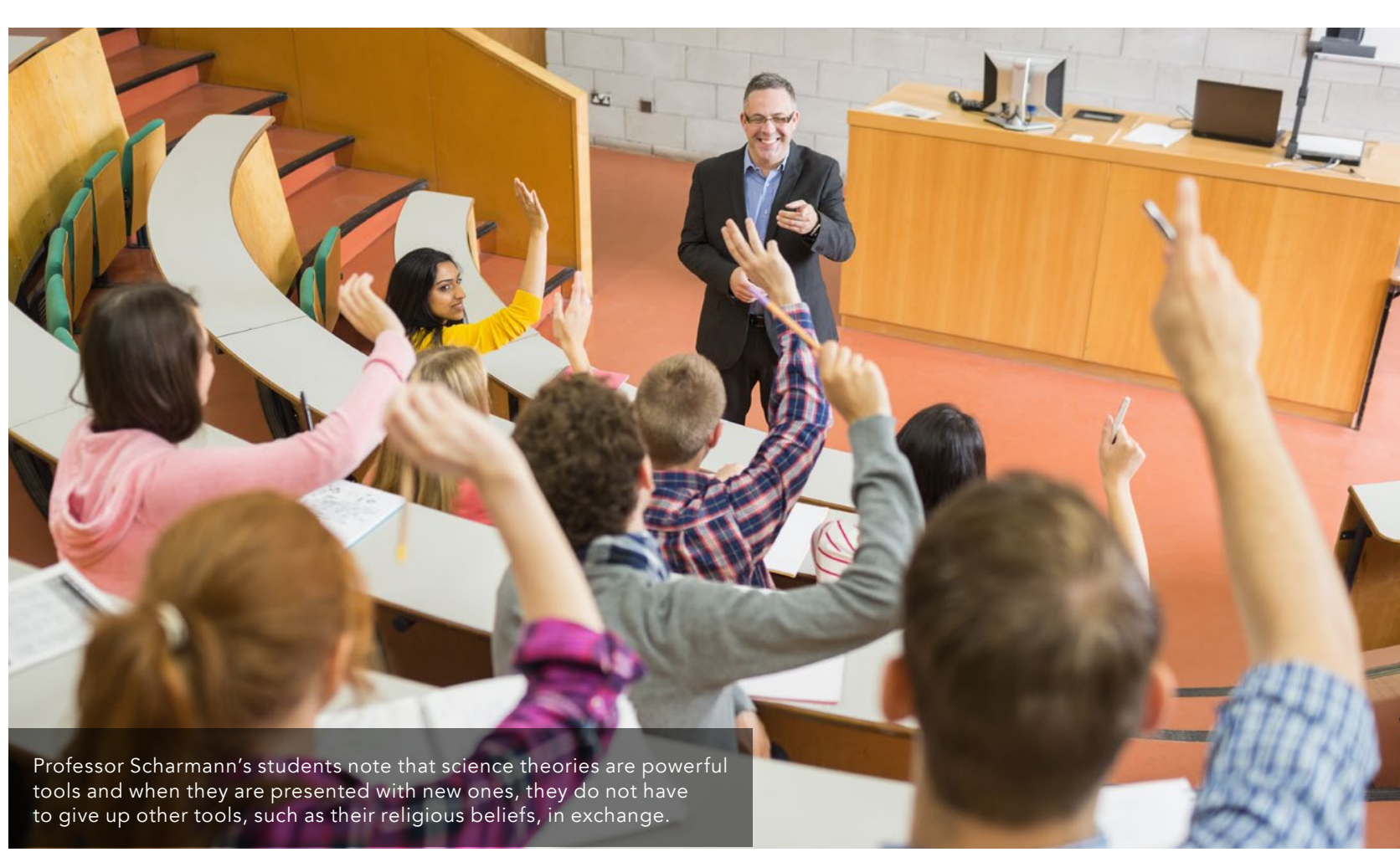

science is consistent with NOS principles. He has used his revised pedagogy for over a decade and been recorded repeatedly in his cours evaluations. Firstly, students note that science theories are powerful tools as distinct from facts or beliefs. They can use these tools to predict, explain and solve scientific problems. Secondly, when presented with new theories, or tools, such theory, students do not have to give up other tools, beliefs or aesthetic preferences that they find valuable in non-scientific situations, in

exchange. Thirdly, methodological naturalism, where scientists choos not to consider supernatura causes (e.g. God and angels) when conducting scientific study, means that scientists must ignore explanations that are outside the realms of science. Professo Scharmann observes that these claim promote a learning environment that is more receptive to studying scient theories, particularly evolution. of evolutionary theory. NON-THREATENING ALTERNATIVE ASSESSMENTS Professor Scharmann and his colleagues have observed how non-threatening

Scharmann reassures his students that their participation is without negative consequence and that the information that they are recording is not being judged as right or wrong. His research studies involving the use of journals nts' learning revealed that journalling promotes students' reflection on the special nature of scientific knowledge. This reinforces the NOS principles that science is necessarily uncertain, testable replicable, and that provide scientists with explanatory their thoughts power... often leads to a revision and products of their worldview. of science, that evidence

a journal where they can engage in selfexamination and record the ongoing changes in their understanding, together with their personal views, has proven successful. This approach is highly dependent, however, on the instructor's ability to provide students with feedback that is consisten unbiased, and non-threatening. JOURNALS TO ASSESS STUDENT LEARNING is required and noting how various empirical methods, such as inference, inference and deduction are shared. The significance an elements of science was also chronicled, with recounts of that scejce aims for objectivity but erect eradicated. The students recognising influences can have and cultural science. The students also reflected on the compatibility of the reflected 
they were learning with their own prior religlous beliefs. Moreover, they with changes in their persona understanding of science concep and discover ways to accept concepts such as evolution and still hold onto particular religious beliefs.

\section{RECONCILING PERSONAL} RELIGIOUS VALUES

his work with future science teachers, Professor Scharmann has found that is important for students to reconcile their worldview, and in particular their personal religious values with their understanding of scientific theories. Science teacher education can help teachers and students articulate and valuate ways of integrating science Wh foster gre frem uno in order the nature of science and biology. The literature demonstrates that many scientists and theologians believe that there is not necessarily conflict between science and religion and a wide range of interpretations of the link between science and religion are presented. Other studies disclose how acknowledging students' different beliefs can generate an increase in the students' ability to reconcile their religious views with aspects of evolutionary science. For the very religious students, Professor scharmann finds that viewing scien and religion as separate, nonoverlapping domains and presenting cience as one of a number of productive aproaning or the teaching and learning of evolution. Professor Scharmann explains that if students "accomplish this reconciliation, they become far more adept at facilitating their future students in learning

\section{PRACTICAL SIGNIFICANCE} OF EVOLUTIONARY CONCEPTS

In addition to interlinking the concepts of evolution with NOS principles, Professor Scharmann finds that it is equally valuable to show the practical significance of evolutionary concepts, demonstrating the human efements that iluminate the relevance and societal decision making. For

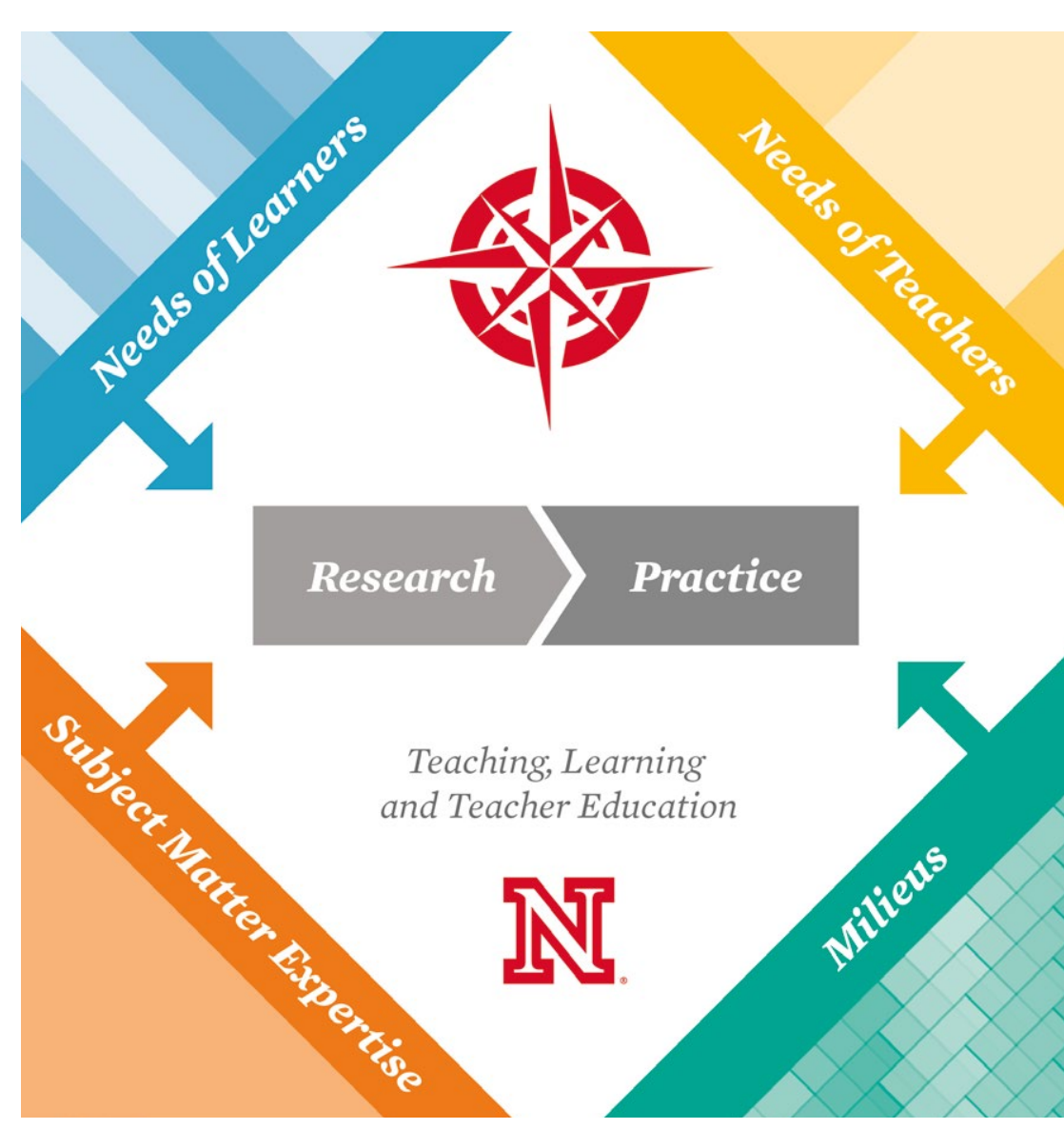

Curriculum Features of Effective Pedagogy
(based on the work of curriculum theorist Joseph J. Schwab)

If students accomplish this reconciliation, they become far more adept at facilitating their future students in learning concepts such as evolution.

instance, he wants his students to understand how it's the collective within a species that adapt to the environment over time and why acquired traits like musical ability are not inherited. Similarly, he wants his students to appreciate how the principles of common ancestry are applied, by the Centers for Disease Control and Prevention, in the design and production of vaccines.

\section{EFFICACIOUS TEACHING}

\section{OF EVOLUTION}

To advance the effective teaching of evolution, Professor Scharmann research demonstrates that science teacher education must ensure th econdary biology teachers have
NOS. Teachers should also be provided with the implications thatents cope evolution. It is also essential that these teachers have an understanding active, social learning. Professor Scharmann suggests teachers use NOS as a lens for evolution instruction with alternative explanations. Where possible, teachers should focus on human evolution and recognise the power of historical inference.

In addition to the scientific strength of evolution, Professor Scharmann highlights the need to help students understand "why a wide array of and religion in persor combining science of appropriate pedagogy and use and that they compare evolution

\section{Behind the Research}

Lawrence C. Scharmann

Ischarmann2@unl.edu T: $+1402472-2231$

.https://scholar.google.com/citations?hl=en\&user=ixTKsvAAAAAJ\&view_op=list_works

Research Objectives

Prof Lawrence Scharmann specialises in science teacher education, focusing on nature of science issues with specific emphasis on the instructional role of science theories (specifically evolution). His seminal contribution have been independently acknowledged by both the National Association for Research in Science Teaching

\section{Detai}

Lawrence Scharmann

114 Henzlik Hall, Department of Teaching

Learning, and Teacher Education

incoln, Nebraska 68588-0355 USA

Bio Hen appointed Assistant Professor of Biology, Indiana University of Pennsylvania, before moving to Kansas State University in 1988, where he was made full Professor In 1996. In 2010, he moved to Florida State University to take the position of Assistant Dean/Director of the School of Teacher Education, and was also Anne \& John Daves Distinguished Professor of Education, College of of Chair at the Department of Teaching Learning and Teacher Education; and is currently an endowed Professor of Education, College of Education and Human Sciences, University of Nebraska-Lincoln.

\section{Funding}

National Science Foundation supported the Nature of Science and Premises of Evolutionary Theory (NOSPET) project.

Collaborators Mike U. Smith, Professo Mercer University of Medicine (retired) Craig E. Nelson, Mentor and Professor Emerit Indiana University

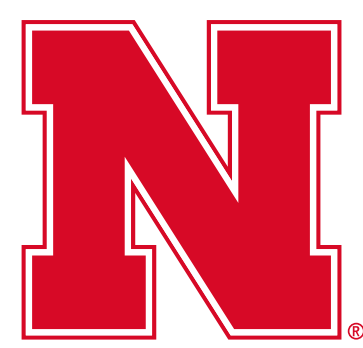

\section{References}

Nelson, C.E., Scharmann, L.C., Beard, J. et al. (2019). The nature of science as a foundation for fostering a better understanding of evolution. Evolution. Education and Outreach, [online] 12, 6. doi:10.1186/s12052-019-0100-7

Scharmann, L.C. (2018). Evolution and nature of science instruction. Evolution. Education and Outreach, [online] 11, 4. https://doi.org/10:1186/s12052-018-0088-4

Scharmann, L.C. \& Butler, W. (2015). The Use of Journaling to Assess Student Learning and Acceptance of Evolutionary https://www.jstor.org/stable/43631880

Winslow, M., Staver, J., \& Scharmann, L.C. (2011). Evolution and personal religious belief: Christian university biologyrelated majors' search for reconciliation. Journal of Research in Science Teaching, 48, 1026-1049. DOI: 10.1002/tea.20417

Scharmann, L.C., Smith, M.U., James, M.C., \& Jensen, M. (2005). Explicit reflective nature of science

instruction. Evolution, Intelligent design, \& Umbrellaology. Journal of Science Teacher Education, 16, 27-41. https://doi. org/10.1007/s10972-005-6990-y

\section{Personal Response}

\section{What prompted your interest in evolution education?}

Theodosius Dobzhansky, a preeminent biologist once remarked that "nothing in biology makes sense except in the light of evolution." Marvelling at the immense powe of this theory to expl" Marn, predict, and solve so many why others saw evolution as controversial.

\section{What are your plans for future research in this area?}

I am working with a former doctoral student to follow a random sample of my science teacher graduates during their initial years of professional teaching practice to emotional (affective) reactions when they first introduce evolution as a unit of study. 